\title{
Risk Evaluation and Financial analysis for Road Maintenance on Urban Expressway Based on H-BMS
}

\author{
Yasuhito SAKAI \\ Hanshin Expressway Company Limited, Osaka, Japan \\ Mitsuru JIDO \\ Chuo Hukken Consultants Co., Ltd., Osaka, Japan \\ Hitoshi FURUTA \\ Department of Informatics of Kansai University, Osaka, Japan \\ Kiyoshi KOBAYASHI \\ Graduate School of Management, Kyoto University, Kyoto, Japan
}

\begin{abstract}
Hanshin Expressway Public Corporation had been privatized in 2005 and has responsibility for maintaining service level of civil structures at sound condition and completely paying off its debt within 45 years after privatization. Therefore, it is an important issue to establish maintenance and rehabilitation plan considering the payment of the debt. This study addresses on Hanshin Expressway asset management system considering internal control and risk management system. Concretely, first of all, business process of Hanshin Expressway is constructed in terms of internal control and risk management. On the other hand, uncertainty of deterioration process is treated as risk, and the relationship between this deterioration risk and maintenance/rehabilitation cost is verified. Based on the risk evaluation result, this study tries to calculate financial information which can be used to making debt payment plan. Finally, for continuous improvement of the business process, extraction of the high priority monitored structures is discussed based on relative evaluation method of deterioration rate of each structure using benchmarking analysis.
\end{abstract}

\section{INRODUCTION}

4 Highway Public Corporations including Hanshin Expressway Public Cooperation have privatized in 2005 , to maintain highway asset service level and complete their debt repayment within 45 years after privatization. The Japan Expressway Holding and Dept Repayment Agency (hereafter referred to as "the Agency") has established in order to secure repayment of interest-bearing debt at the same time of privatization.

Highway asset and debt has been transferred from highway companies to the Agency (Highway companies leases the asset from the Agency and imply maintenance and rehabilitation activities. Highway companies have to pay lease fees out of incomes from tolls, excluding costs for expressway maintenance and management, to the Agency. The Agency repays the debt with the lease fees. Highway companies and the Agency conclude agreements about debt repayment plan and highway asset service level about every 5 years. Therefore, Highway companies should carry out rational maintenance management of highway, considering debt repayment plan concluded in the agreement. Due to the length of the planning period, highway companies are exposed to deterioration risk

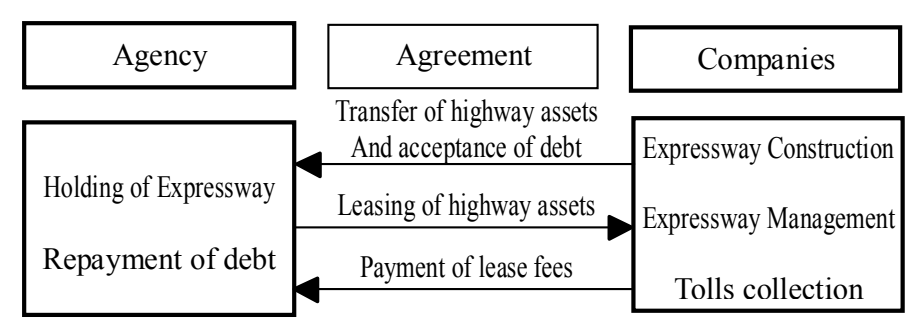

Figure 1. Scheme of Implementation of Expressway Business Activities by the Agency and Companies

and traffic fluctuation risk. Deterioration risk has large influence to the highway company's long-term financial condition, so that it must be controlled appropriately.

In order to implement practical maintenance management, two kind of work must be necessary, $1^{\text {st }}$, work for preparing maintenance and rehabilitation plan to maintain highway service level in proper condition and to complete repayment of debt, $2^{\text {nd }}$, work for constructing business process systems in which the plan can be implied, evaluated, and improved. $1^{\text {st }}$ work includes two types of activities.

The $1^{\text {st }}$ activity is to repair deteriorated components in order to maintain in good condition. Hanshin Expressway has developed bridge management system named "H-BMS", which calculate deterioration curve (deterministic calculation) from visual inspection data 
and estimate future maintenance and rehabilitation costs. This BMS must be improved to evaluate deterioration risk by introducing stochastic deterioration model(Sakai et al. 2009).

The $2^{\text {nd }}$ activity is to replace or improve parts intensively in order to get better service level. This activity should be the overriding priority for Highway company.

For $2^{\text {nd }}$ work, Hanshin Expressway has also developed Logic Model for continuous evaluations of Hanshin Express way maintenance management along with H-BMS development (Sakai et al. 2007).

Highway companies must secure efficiency and transparency of their maintenance management because of their high public responsibilities for maintaining road network systems. Therefore, they should adopt internal control system to maintenance management. The Internal Control system is one of the methods to control business risk. Maintenance management directly affects on the service level of highway assets. Therefore, Highway companies need to develop business process system for evaluating and managing business risk on maintenance management.

This study proposes practical business process system which enable to implement risk management for maintenance and rehabilitation costs and better service level. In the framework of proposed business process system, this study tries to get financial information for debt repayment plan, along with relationship between deterioration risk and maintenance and rehabilitation costs. This study also tries to develop methodology that overriding priority problem is able to pick up by benchmarking analysis.

\section{BUSINESS PROCESS SYSTEM}

\subsection{Assumptions for developing Business process system}

\subsection{1 hierarchical structure}

Figure 2 shows the hierarchical structure of three level in enterprise risk management (Study Group on Risk Management and Internal Control. 2003). Top rank level is defined as "Management Level", middle rank level is defined as "Manager Level", third rank is defined as "Staff Level".

Hanshin Expressway has same structure as Figure 2 in their maintenance management business process, they have "Management Level" who decide maintenance policy, they have planning group in which maintenance and rehabilitation plan is planned and annual budget allocation is implemented, and also they have maintenance management department in which main-

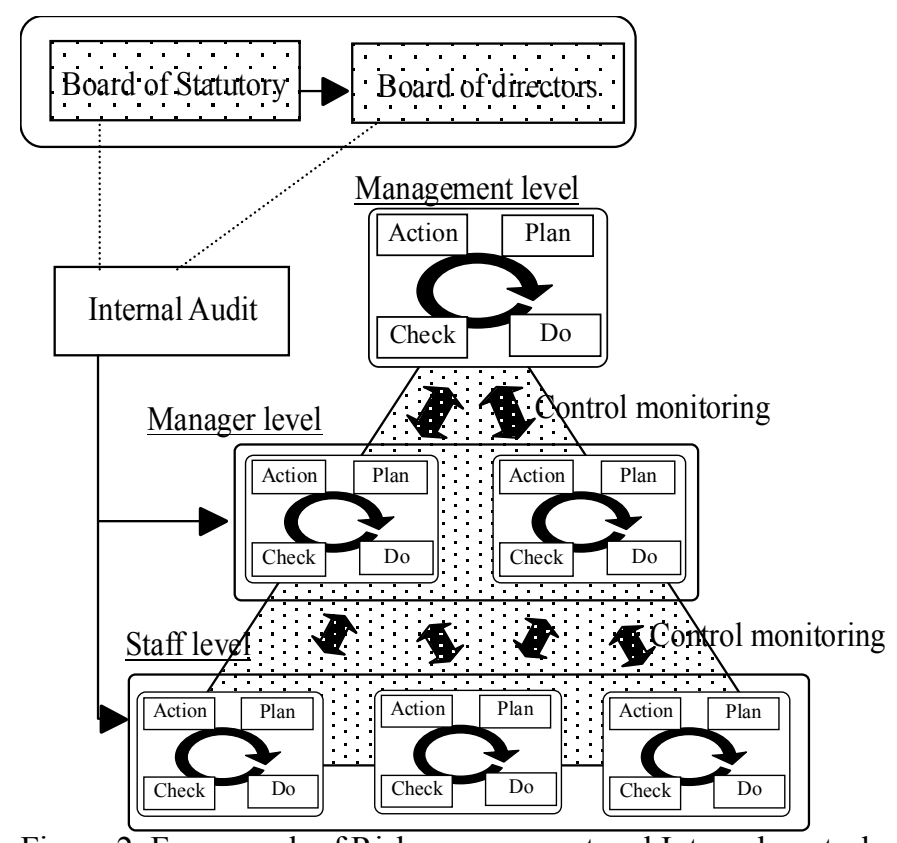

Figure 2. Framework of Risk management and Internal control

tenance and rehabilitation activities are implemented.

Therefore, in this study these groups are defined as

"Management level", "Planning level", and "Practical level" from its top to bottom.

\subsubsection{Management cycle}

Management cycle which is composed of "plan", "do", "check", "action" is necessary for continuous improvement of enterprise business.

\subsubsection{Management cycle for engineering improve- ment}

Maintenance management is one of the most important business in Hanshin Expressway, so that extracting and solving companywide problems is necessary to achieve continuous improvement in maintenance management.

The improvement activity on fatigue damage at the beam-column connection of steel pier is one of the examples of extracting and solving companywide problems in Hanshin Expressway. However, most of these improvements have been implemented after the damages were identified. If the improvement activities are involved in one of the sub-systems of business process system, companywide problems are continuously found out, and as a result it can be improved before the problems are identified.

\subsubsection{Hierarchical Structure of Management cycle}

This study assumes 2 type of management cycle. One is upper rank management cycle for deciding longterm maintenance and rehabilitation plan, the other is lower rank for implying maintenance and rehabilitation. This study calls upper rank management cycle as 


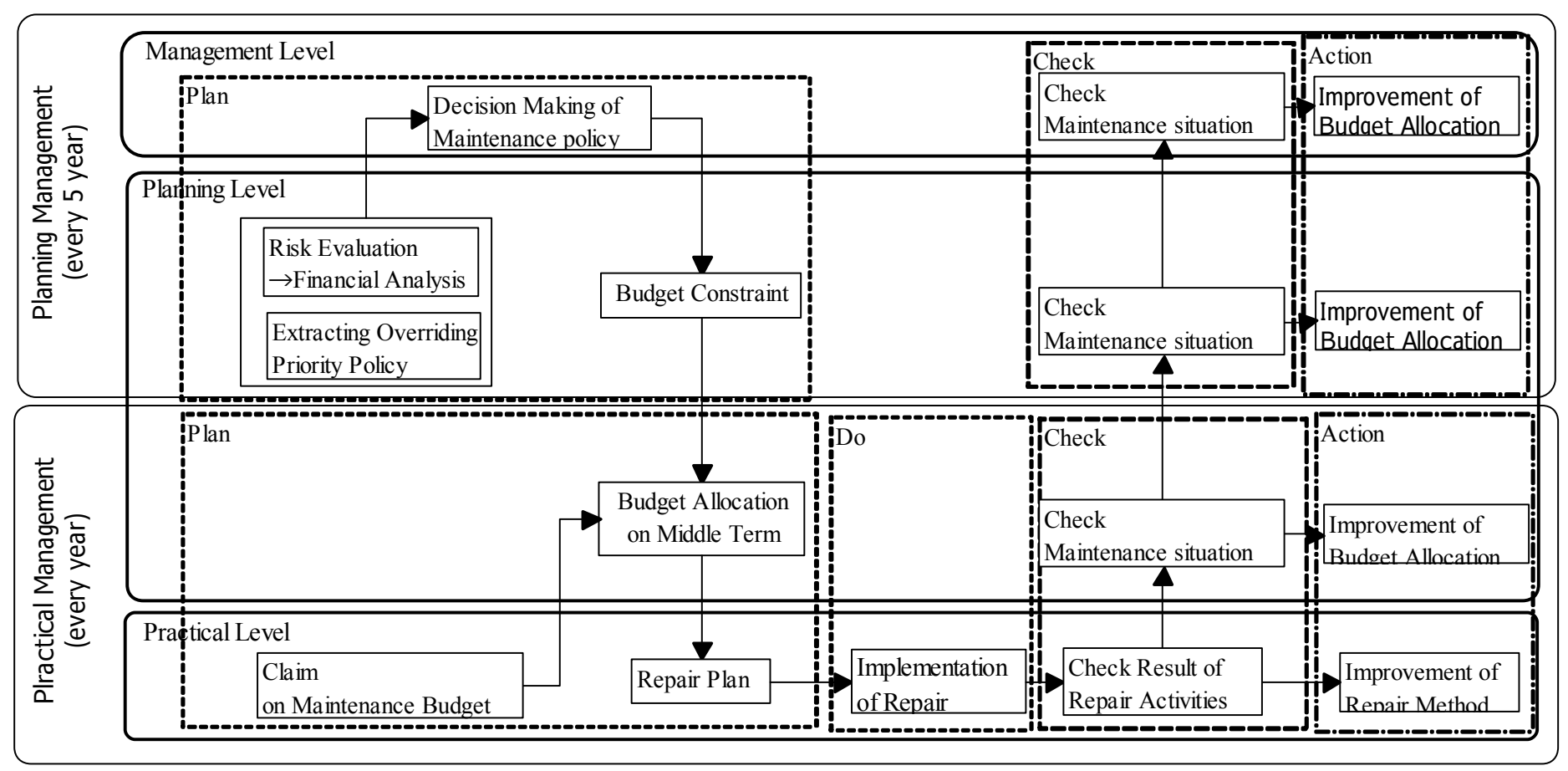

Figure 3: Framework of Business Process System

"Planning Management", and lower rank as "Practical Management".

\subsubsection{Business Process System}

Figure 3 shows business process system including risk management of Hanshin Expressway.

\subsubsection{Management Level}

This level is composed of executives, decides maintenance policies according to several maintenance plans and overriding priority policy prepared in Planning Level which is described later.

\subsubsection{Planning Level}

This level prepares long-term maintenance plan, extracting overriding priority, and allocates annual maintenance and rehabilitation budget. H-BMS is useful in this level.

\subsubsection{Practical Level}

This level implements maintenance and rehabilitation in allocated budget.

\subsubsection{Planning Management}

In this management, optimum maintenance costs and service level of expressway asset are calculated to conclude agreements, and make decision of maintenance policies.

a) Deriving optimum maintenance costs

Optimum maintenance costs and service level should be calculated from risk evaluation and financial analysis. b) Concluding agreements

According to optimum maintenance policy derived from risk evaluation and financial analysis, Hanshin Expressway concludes agreements to the Agency.

c) Decision making of maintenance policies

Through a) and b), maintenance policy is determined. This policy must be decided through quantitative evaluation about relationship between maintenance costs and deterioration risk, because that relationship affects agreements concluded with the Agency.

d) Practical management

In this management, maintenance and rehabilitation activities are implemented under the conditions of budget and recommended service level which are optimized in Manager level.

\section{OVERRIDING PRIORITY POLICY}

\subsection{Extracting of overriding priority policy by benchmarking approach}

Condition states of bridge components are observed by periodical visual inspections with interval from 4year to 8-year. According to the accumulated time series condition state (see table 3 ) data, there are some components under same structural characteristics that the condition state transit from "OK" to "A" within 5 years, or transit from "OK" to "B" in short interval. Although life cycle of bridge is generally over 50 years, these rapid deteriorated components may have some unidentified problems. If these problems are 
continuously improved as overriding priority policy after extracted by benchmarking approach (Nam et al. 2008), the service level of Hanshin Expressway asset will be continuously improved. As a result, maintenance cost will be reduced.

\subsection{Methodology of Benchmarking approach method}

Benchmarking approach is one of the methods to evaluate heterogeneity of deterioration process of individual bridge components which are under the same structural characteristics and environmental condition. This method regards exponential hazard function (equation (1)) as benchmark which is statistically calculated from visual inspection data.

$$
\lambda_{i}\left(y_{i}\right)=\theta_{i}
$$

i : condition state of component

$\lambda_{i}\left(y_{i}\right)$ : hazard function

$y_{i}:$ time point

$\theta_{i}:$ constant(independent from time)

Marcov transition probability is represented as follows (Tsuda et al. 2006).

$\pi_{i i}=\exp \left(-\theta_{i} Z\right)$

$\pi_{i i+1}=\frac{\theta_{i}}{\theta_{i}-\theta_{i+1}}\left\{-\exp \left(-\theta_{i} Z\right)+\exp \left(-\theta_{i+1} Z\right)\right\}$

$\pi_{i j}=\sum_{k=i}^{j} \prod_{m=i}^{k-1} \frac{\theta_{m}}{\theta_{m}-\theta_{k}} \prod_{m=k}^{j-1} \frac{\theta_{m}}{\theta_{m+1}-\theta_{k}} \exp \left(-\theta_{k} Z\right)$

$(j=1, \cdots, J)$

$\pi_{i J}=1-\sum_{j=i}^{J-1} \pi_{i j}(i=1, \cdots, J-1)$

$\mathrm{Z}:$ inspection interval

$i$ : condition state before transition

$\mathrm{j}$ : condition state after transition $(\mathrm{j}>\mathrm{i}+1)$

Marcovian transition probability matrix is represented by equation (6).

$\prod(Z)=\left[\begin{array}{ccc}\pi_{11}(Z) & \cdots & \pi_{i J}(Z) \\ \vdots & \ddots & \vdots \\ 0 & \cdots & \pi_{J J}(Z)\end{array}\right]$

Heterogeneity factor of component $\mathrm{k}$ is defined as $\varepsilon^{k}$, then hazard function of component $\mathrm{k}$ is represented as follows.

$\lambda_{i}^{k}\left(y_{i}\right)=\lambda_{i}\left(y_{i}\right) \times \varepsilon^{k}$
Table 1:Damage Ranking of Periodical Inspection

\begin{tabular}{l|ll}
\hline \multicolumn{2}{l}{ Rank } & Description \\
\hline \hline & S1 & $\begin{array}{l}\text { Significant performance decline is noted, } \\
\text { suggesting need for immediate action from } \\
\text { the viewpoint of safety of the road structure. }\end{array}$ \\
& S2 & $\begin{array}{l}\text { Impact to third parties is predicted, suggest- } \\
\text { ing need for immediate action. }\end{array}$ \\
A & $\begin{array}{l}\text { Performance decline is noted, suggesting } \\
\text { need for action. }\end{array}$ \\
B & $\begin{array}{l}\text { Continued monitoring is needed on damage } \\
\text { condition. }\end{array}$ \\
C & $\begin{array}{l}\text { Damage is minor } \\
\text { (for periodic inspection only). }\end{array}$ \\
OK & Not applicable to any of the above. \\
\hline
\end{tabular}

Table 2: Inspection Frequency

\begin{tabular}{lll}
\hline $\begin{array}{l}\text { Subject } \\
\text { structures }\end{array}$ & $\begin{array}{l}\text { Inspection } \\
\text { frequency }\end{array}$ & Inspection method \\
\hline $\begin{array}{l}\text { Whole bridges and } \\
\text { culverts }\end{array}$ & $\begin{array}{l}\text { Every four (4) to } \\
\text { eight (8) years }\end{array}$ & $\begin{array}{l}\text { Close visual } \\
\text { inspection }\end{array}$ \\
Pavement & $\begin{array}{l}\text { Every two (2) to } \\
\text { three (3) years }\end{array}$ & $\begin{array}{l}\text { Automatic mea- } \\
\text { surement vehicle }\end{array}$ \\
Earthworks & Yearly & $\begin{array}{l}\text { Close visual } \\
\text { inspection }\end{array}$ \\
Tunnels & Every five (5) years & $\begin{array}{l}\text { Close visual } \\
\text { inspection }\end{array}$ \\
& & \\
\hline
\end{tabular}

Table 3: Example of time series inspection result

\begin{tabular}{lllllll}
\hline $\begin{array}{l}\text { Bridge } \\
\text { ID }\end{array}$ & $\begin{array}{l}\text { Inspection } \\
\text { year }\end{array}$ & Rank & $\begin{array}{l}\text { Inspection } \\
\text { year }\end{array}$ & Rank & $\begin{array}{l}\text { Inspection } \\
\text { year }\end{array}$ & Rank \\
\hline \hline 281 & 1989 & OK & 1992 & B & 1997 & A
\end{tabular}

$\begin{array}{lllllll}357 & 1989 & \text { OK } & 1992 & \text { A } & 1997 & \text { A }\end{array}$

$\begin{array}{lllllll}319 & 1989 & \text { OK } & 1992 & \text { A } & 1997 & \text { B }\end{array}$

$\begin{array}{lllllll}4-8 & 1994 & \text { OK } & 1998 & \text { B } & 2003 & \text { C }\end{array}$

$\begin{array}{lllllll}3 & 1992 & \text { OK } & 1996 & \text { B } & 2002 & \text { OK }\end{array}$

Heterogeneity factor $\varepsilon^{k}$ is assumed as a probability sample extracted from Normal Gamma distribution (equation (8)). 


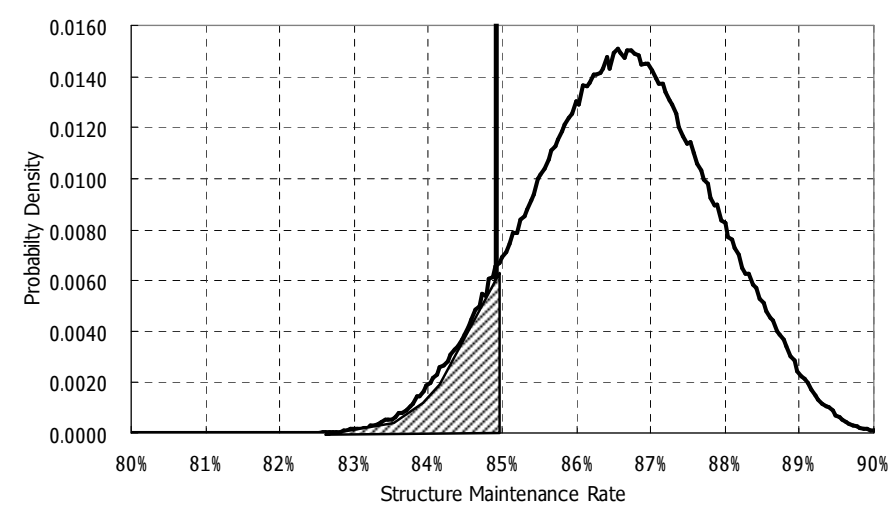

a) Distribution of Probability Density

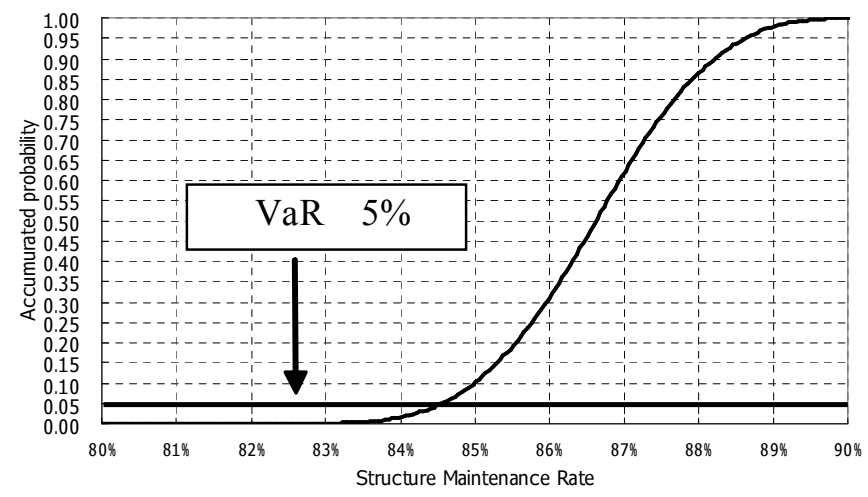

b) Distribution of Accumulated Probability

Figure 4: Example of distribution of Structure Maintenance Rate

$f\left(\varepsilon^{k}: \phi\right)=\frac{\phi^{\phi}}{\Gamma(\phi)}\left(\varepsilon^{k}\right)^{\phi-1} \exp \left(-\phi \varepsilon^{k}\right)$

Mean value of this distribution is 1.0 and variance is $1 / \phi$. Then, next equation is derived.

$\int_{0}^{\infty} \lambda_{i}^{k} f\left(\varepsilon^{k}, \phi\right) d \varepsilon=\lambda_{i} \int_{0}^{\infty} \varepsilon^{k} f\left(\varepsilon^{k}, \phi\right) d \varepsilon=\lambda_{i}$

\section{FINANCIAL ANALYSIS BASED ON RISK EVALUATION}

\subsection{Risk Evaluation}

Fig. 4 shows the distributions of Structure Maintenance Rate(see equation.(10)) of pre-stressed concrete beams at 2050 which is calculated by 10,000 times Monte Carlo Simulations on condition that beams are repeatedly repaired when those condition state become "A", or "S". Fig. 4a shows the probability density, and b) shows accumulated probability. Evaluating deterioration risk, Hanshin Expressway calculates probabilities of Structure Maintenance Rate under budget constraint. In this study, let this probability be determined as $\mathrm{VaR}$ (Value at Risk). Horizontal line in Fig. 4b

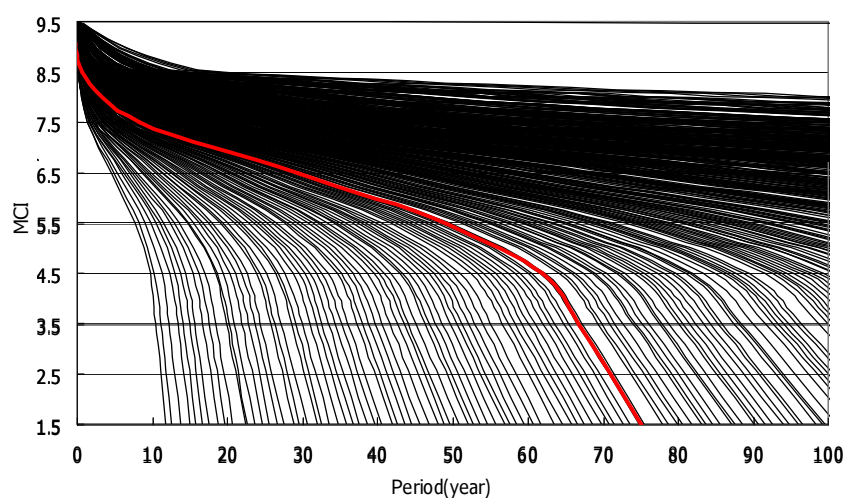

a) Concrete Deck

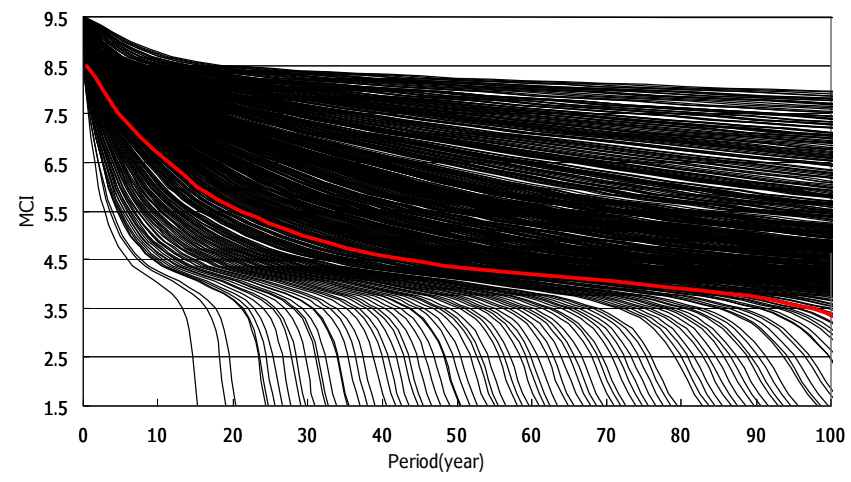

b) Metal Deck

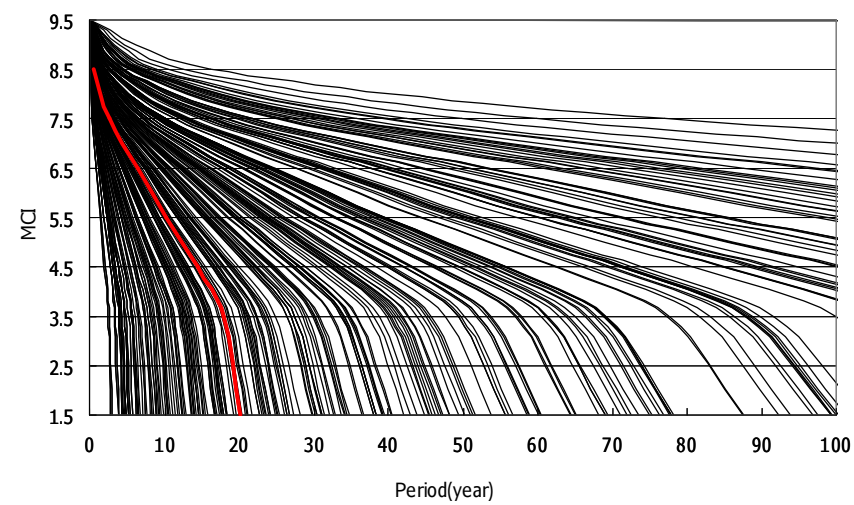

c) Earth work

Figure 5:Result of Benchmarking Analysis on Pavement

shows the service level which VaR is $5 \%$. Structure Maintenance Rate of this line represents $84.5 \%$. The area bellow this line is excluded as considered risk.

\subsection{Methodology of financial analysis.}

Expenditure for maintenance is classified into capital expenditure and revenue expenditure. Revenue expenditure is able to finance out of incomes from tolls, but capital expenditure have to finance with other way, e.g. debt. Debt of expressway company is transferred to the Agency at the end of fiscal year, as a result debt of the Agency increases. Therefore, future transition of two kind of expenditure is very important 
for financial analysis. Financial analysis of this study is to calculate the transition of these expenditures

\section{EMPIRICAL STUDY}

\subsection{Extracting Overriding Priority Policy}

Figure 5 shows results of benchmarking approach on pavement. This figure shows three kind of results according to the structure under base course. Due to the structural difference under surface and base course of asphalt pavement, deterioration speed is different form each other. Deterioration speeds of each components are widely different in same structure. If the components with relatively faster deterioration speed are investigated in detail, overriding priority policy for highway company is able to extracted.

\subsection{Risk evaluation}

\subsubsection{Overview of Risk evaluation}

This study implements risk evaluation for about 234 km length overhead structures of Hanshin Expressway. Firstly, this study calculates deterioration speed from periodical inspection data which are accumulated in Maintenance Information Management System, secondly, estimates future maintenance costs, and finally, implements financial analysis. Due to uncertainty of deterioration process, stochastic deterioration model is necessary for estimating future maintenance costs and service level of highway assets. Expected maintenance costs which can achieve object service level with $90 \%, 95 \%$, and $99 \%$ liability under budget constraint from 2009 to 2050 are calculated by Monte Carlo Simulation for 8 structures which are Pavement, Paint, Expansion joint, Concrete beam, Metal beam, Concrete pier, Concrete deck, Bearing Point.

This study considers uncertainty of deterioration as risk, and transition probability matrix is used as deterioration model.

The service level is defined as follows

Pavement Maintenance Rate

$=\frac{M C I \geq \text { pavement length which } \mathrm{MCI} \text { is over } 4.0}{\text { Total pavement length }}$

Structure Maintenance Rate

$=1-\frac{\text { Number of } \operatorname{span}(\text { pier) with condition state A,S }}{\text { Total number of span(pier) }}$

This study assumes that repair activities are implemented at the condition state A, S which are shown in table 1, and deterioration process after the repair is
Table 4: Estimation result in case with VaR 5\%

\begin{tabular}{|c|c|c|c|c|}
\hline \multirow[t]{2}{*}{ Structure } & \multirow{2}{*}{$\begin{array}{c}\text { Latest } \\
\text { Service } \\
\text { Level }\end{array}$} & $\begin{array}{c}\text { Service Level } \\
\text { at } 2050 \\
\end{array}$ & $\begin{array}{c}\text { Budget } \\
\text { Constraint }\end{array}$ & $\begin{array}{c}\text { Expected Expen } \\
\text { ture }\end{array}$ \\
\hline & & 95\%liability & \multicolumn{2}{|c|}{ million\$/year } \\
\hline Pavement & $99.49 \%$ & $100.00 \%$ & $\begin{array}{c}\text { Repair budget } \\
4.50\end{array}$ & $\begin{array}{l}\text { Repair } 4.33 \\
\text { Maintenance } 3.42\end{array}$ \\
\hline Paint & $98.26 \%$ & $98.40 \%$ & 17.00 & 14.24 \\
\hline $\begin{array}{l}\text { Expansion } \\
\text { joint }\end{array}$ & $94.73 \%$ & $96.00 \%$ & 19.50 & 19.48 \\
\hline $\begin{array}{l}\text { Concrete } \\
\text { beam }\end{array}$ & $87.49 \%$ & $90.30 \%$ & 4.00 & 3.96 \\
\hline $\begin{array}{l}\text { Metal } \\
\text { beam }\end{array}$ & $98.57 \%$ & $99.50 \%$ & 0.90 & 0.82 \\
\hline $\begin{array}{l}\text { Concrete } \\
\text { pier }\end{array}$ & $95.82 \%$ & $99.80 \%$ & 3.50 & 3.41 \\
\hline Deck & $99.72 \%$ & $100.00 \%$ & 0.40 & 0.31 \\
\hline $\begin{array}{l}\text { Bearing } \\
\text { point }\end{array}$ & $96.72 \%$ & $98.70 \%$ & 2.00 & 1.85 \\
\hline
\end{tabular}

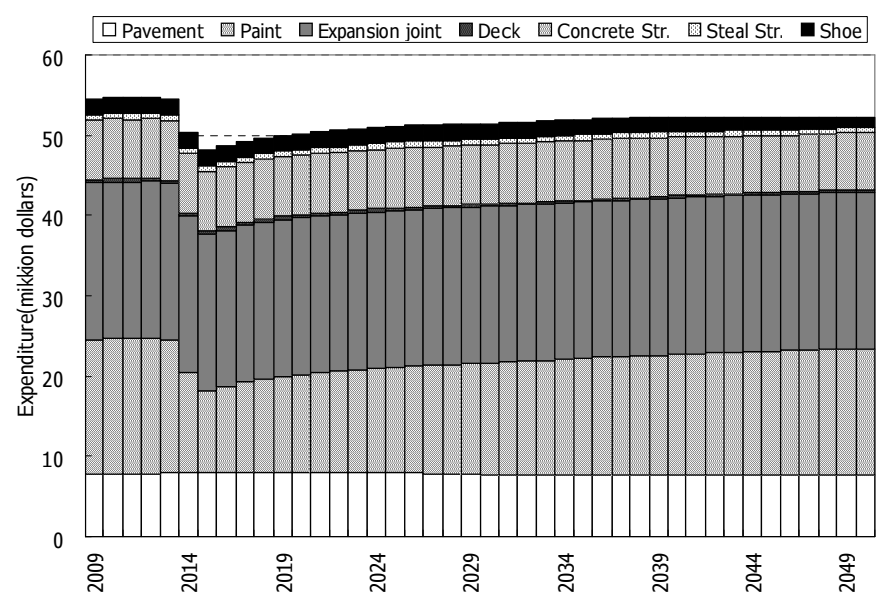

Figure 7: Expenditure transition in case with VaR 5\%

same as the deterioration process before repair, and condition state just after repair is OK.

Annual budget constraint rule is given as follows. Annual budget constraint is given for 8 structures respectively. If repair for components with condition state A,S is completed within budge constraint, and the budget is still remained, then extra repair for components with condition state $\mathrm{OK}, \mathrm{C}, \mathrm{B}$ is assumed not be implemented.

\subsubsection{Result}

Table 4-6 shows the calculation result of risk evaluation. Table 4 shows annual budget constraint and estimated annual expenditure in case with VaR 5\%. In this case, objective service level can be maintained with $95 \%$ reliability. Table 5 shows the case with VaR $1 \%$, table 6 shows the case with VaR 10\%. Fig. 7 shows the transition of expected maintenance costs in case with VaR 5\%. "Latest Service Level" is calculated value based on latest inspection data. "Budget Constraint" is annual upper limit of expenditure for 42 
Table5:Estimation result in case with $\mathrm{VaR}=1 \%$

\begin{tabular}{|c|c|c|c|c|}
\hline \multirow[t]{2}{*}{ Structure } & \multirow{2}{*}{$\begin{array}{c}\text { Latest } \\
\text { Service } \\
\text { Level }\end{array}$} & $\begin{array}{c}\text { Service Level } \\
\text { at } 2050 \\
\end{array}$ & $\begin{array}{c}\text { Budget } \\
\text { Constraint } \\
\end{array}$ & $\begin{array}{c}\text { Expected Expend } \\
\text { ture }\end{array}$ \\
\hline & & 95\%liability & \multicolumn{2}{|c|}{ million\$/year } \\
\hline Pavement & $99.49 \%$ & $100.00 \%$ & $\begin{array}{c}\text { Repair budget } \\
4.50\end{array}$ & $\begin{array}{l}\text { Repair } 4.33 \\
\text { Maintenance } 3.42\end{array}$ \\
\hline Paint & $98.26 \%$ & $98.50 \%$ & 18.80 & 14.32 \\
\hline $\begin{array}{l}\text { Expansion } \\
\text { joint }\end{array}$ & $94.73 \%$ & $95.60 \%$ & 19.50 & 19.48 \\
\hline $\begin{array}{l}\text { Concrete } \\
\text { beam }\end{array}$ & $87.49 \%$ & $88.90 \%$ & 4.00 & 3.96 \\
\hline $\begin{array}{l}\text { Metal } \\
\text { beam }\end{array}$ & $98.57 \%$ & $99.50 \%$ & 0.90 & 0.82 \\
\hline $\begin{array}{l}\text { Concrete } \\
\text { pier }\end{array}$ & $95.82 \%$ & $99.60 \%$ & 3.50 & 3.41 \\
\hline Deck & $99.72 \%$ & $100.00 \%$ & 0.40 & 0.31 \\
\hline $\begin{array}{l}\text { Bearing } \\
\text { point }\end{array}$ & $96.72 \%$ & $98.00 \%$ & 2.00 & 1.85 \\
\hline
\end{tabular}

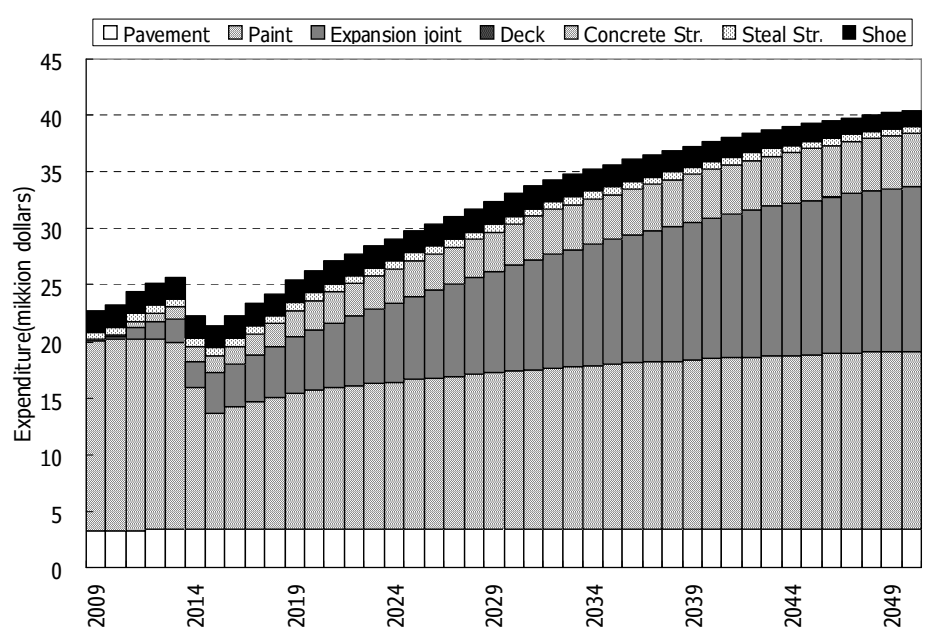

Figure 8: Transition of revenue expenditure

years from 2009 to 2050. "Expected Expenditure" is the expectation of expenditure per a year simulated by Monte Carlo Simulation for 42 years. Expected expenditure is different form budget constraint because some times repair expenditure for condition state $\mathrm{A}, \mathrm{S}$ is less than budget. Central column of table 4 shows calculated service level of $95 \%$ reliability in 2050 which is the final year of debt repayment. Calculated annual repair cost is about 51.8 million dollars. This expenditure is minimum in 2014, because repair expenditure of paint is less than budget constraint due to the completion of necessary quantities before 2014 . After 2014, repair cost increases with the increase of the number of condition state A, S.

The annual expenditure in case with VaR $1 \%$ is 10 million more dollars than case with VaR 5\%, and 30 million more dollars than case with VaR $10 \%$. If structural safety is the most important to highway maintenance, then 51.9 million dollars per a year is necessary with consideration of $\mathrm{VaR} 1 \%$. But, if $\mathrm{VaR}$
Table 6:Estimation result in case with $\mathrm{VaR}=10 \%$

\begin{tabular}{lcccc}
\hline \multirow{2}{*}{ Structure } & $\begin{array}{c}\text { Latest } \\
\text { Service } \\
\text { Level }\end{array}$ & $\begin{array}{c}\text { Service Level } \\
\text { at 2050 }\end{array}$ & $\begin{array}{c}\text { Budget } \\
\text { Constraint }\end{array}$ & $\begin{array}{c}\text { Expected Expendi- } \\
\text { ture }\end{array}$ \\
\cline { 3 - 5 } Pavement & $99.49 \%$ & $100.00 \%$ & $\begin{array}{c}\text { Repair budget } \\
4.50\end{array}$ & $\begin{array}{c}\text { Repair } 4.33 \\
\text { Maintenance } 3.42\end{array}$ \\
Paint & $98.26 \%$ & $98.90 \%$ & 16.90 & 14.23 \\
$\begin{array}{l}\text { Expansion } \\
\text { joint }\end{array}$ & $94.73 \%$ & $95.80 \%$ & 19.40 & 19.38 \\
$\begin{array}{l}\text { Concrete } \\
\text { beam }\end{array}$ & $87.49 \%$ & $88.30 \%$ & 3.90 & 3.86 \\
$\begin{array}{l}\text { Metal } \\
\text { beam }\end{array}$ & $98.57 \%$ & $99.50 \%$ & 0.90 & 0.82 \\
$\begin{array}{l}\text { Concrete } \\
\text { pier }\end{array}$ & $95.82 \%$ & $98.00 \%$ & 3.40 & 3.38 \\
$\begin{array}{l}\text { Deck } \\
\text { Bearing }\end{array}$ & $99.72 \%$ & $100.00 \%$ & 0.40 & 0.31 \\
point & $96.72 \%$ & $98.00 \%$ & 1.90 & 1.84 \\
\hline
\end{tabular}

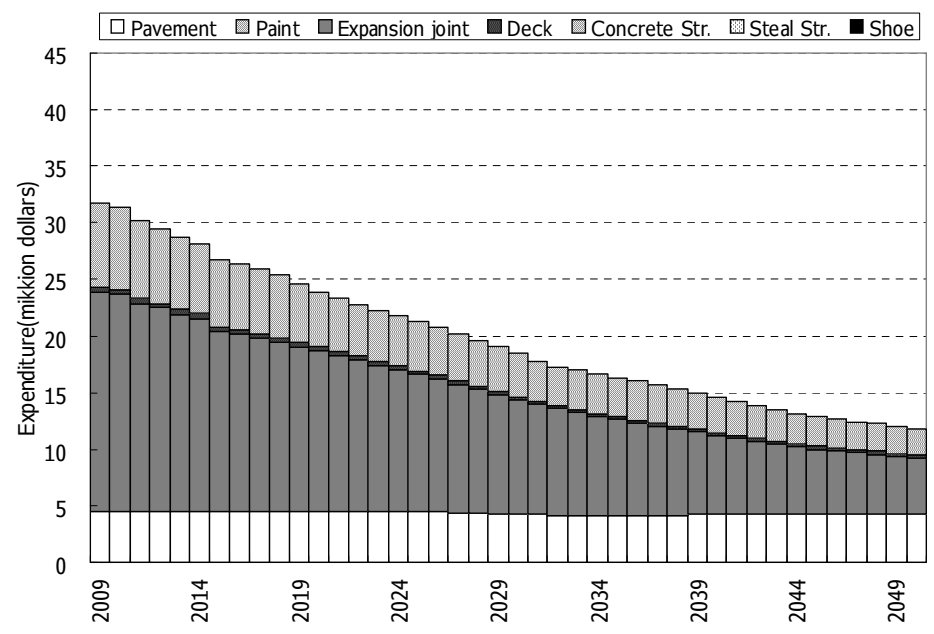

Figure 9: Transition of capital expenditure

$5 \%$ is approvable, then 51.6 million dollars per a year is necessary for maintain highway service level.

According to the result of empirical study, deterioration risk has small effects on maintenance and rehabilitation cost. This is because condition state is able to maintain semi-permanently by repetition of repair.

Fig. 8 and Fig. 9 shows the transfer of revenue expenditure and capital expenditure respectively. Capital expenditure is maximum value in first year of calculation, and gradually decreases as time, because first repair is classified into capital expenditure which is regarded as acquisition of new capital. On the contrary, revenue expenditure increases as time, because repetition of repair is not regarded as acquisition of new capital.

As a result, debt is expected to increase from initial year due to amount of capital expenditure, but as time passing new debt decreases. On the other hand, increase of revenue expenditure with time passage is expected to effect on other business, because revenue expenditure can be financed out of incomes from tolls. 


\section{CONCLUSION}

This study develops the business process system of highway companies and methodology of financial analysis based on risk evaluations. This study clarifies the position and the role of H-BMS in business process system.

According to the result of empirical study, deterioration risk does not have big effect on short-term business risk of Hanshin Expressway. But, this deterioration risk has big effect on long-term business risk. Quantification of relationship between maintenance scenario and its risk is useful for decision making of maintenance policy.

This study makes some assumptions in financial analysis and risk evaluation, therefore, solutions to these assumptions is necessary for the improvement of the accuracy of the study as follows.

First, all given budget is assumed to be able to use only for repair. But, in practice, sudden expenditure except repair is sometimes necessary, so that all budget is not always used for repair. In this case, service level of highway asset might not be maintained with same budget constraint as this study.

Second, sensitivity analysis is necessary to find out parameters which effect on the result of financial analysis and risk evaluation.

Third, development of management accounting is necessary for optimal maintenance management. There are several accounting methods applied to the idea of asset depletion (Kobayashi et al. 2008). And differed maintenance accounting method is suitable in this study.

The result of empirical study is based on some assumptions so that this is an example of the framework of practical highway asset management.

\section{REFERENCE}

Y.Sakai, T.Arakawa, Y.Inoue, H.Furuta \& K.Kobayashi, 2009. The Development of Practical Asset Management System for the Hanshin Expressway Network, The 4th International Conference on Structural Health Monitoring of Intelligent Infrastructure.

Y.Sakai, H.Uetsuka, \& K.Kobayashi, 2007. Feasibility study on risk optimization of expressway maintenance based on HELM logic model (in Japanese), 27th Japan Road Congress.

Study Group on Risk Management and Internal Control. 2003. Internal Control in the New Era of Risks - Guidelines for Internal Control That Functions Togather with Risk Management-.

L.T.Nam, K.Obama, K.Kobayashi 2008. Local mixture hazard model, A semi-parametric approach to risk management system, IEEE International conference on Systems, Man and Cybermetrics,SMC 2008.

Y.Tsuda, K.Kaito, K.Aoki, \& K.Kobayashi. 2006. Estimating marcovian transition probabilities for bridge deterioration forcasting, Journal of Structural Engineering and Earthquake Engineering, 23(2), 241-256.

K.Kobayashi, R.Ejiri, \& M,Do 2008. Pavement Management Accounting System, Journal of Infrastructure Systems, 14(2), $159-168$ 